\title{
Knowledge Level of Women Sarpanch in Gram Panchayats of Navsari District of South Gujarat, India
}

\author{
Payal Patel" and R. M. Naik \\ Department of Extension Education, N. M. College of Agriculture, \\ NAU, Navsari-396450, India \\ *Corresponding author
}

\section{A B S T R A C T}

Keywords

Women sarpanch, Gram Panchayat, Panchayati Raj Institutions

Article Info

Accepted:

04 November 2019

Available Online:

10 December 2019
Women represent half of the population of the country and they have a lot of potential for the development, Even though they have been in negligible number in political sphere. But, presently women slowly moving towards the leadership scale and changing the face of village politics. As Gram Panchayat is the pillar of Panchayati RajInstitutions, the study was conducted with the knowledge level of women sarpanch in Gram Panchayats. Only 100 women sarpanch were selected by simple random sampling from all six Talukas of Navsari District. Interview schedule was used for data collection and the collected data were analyzed by using percentage, mean, standard deviation, rank and correlation coefficient $(r)$. The study found that nearly two third of women sarpanch (61.00 per cent) had medium level of knowledge about fundamental functions of constitutional bodies. Half of the them (50.00 per cent) had moderate level of knowledge about sponsored programme under Panchayati Raj System.

\section{Introduction}

The panchayat has been the basic and important unit in organization of Indian societal polity. The word "Panchayat" literally means assembly of five. The leader of the panchayat was generally called the Sarpanch, an elected position. Panchayats have been the backbone of the Indian villages since the beginning of recorded history, but in this picture frame women is nowhere to be seen.

The women have a lot of potential for the development and they play a very important role in the development process if they participate in decision making in political and developmental activities there for, Article 243$\mathrm{D}$ of $73^{\text {rd }}$ amendment act says that "Not less 
than one-third of total number of seats to be filled by direct election in every panchayat shall be reserved for women".

For empowerment of women in all spheres, one third reservation for women in the Panchayati Raj Institutions is provided by government by means of providing them the opportunity to participate in the administration of local government.

The factors are responsible for bringing political awakening among the women sarpanch is knowledge level about the fundamental functions of constitutional bodies and sponsored programme under Panchayati Raj System which results in sharpen their abilities to perform enthusiastically. Knowledge of women representatives will help them to perform better and bringing change in the rural countryside by bringing social development.

To study the knowledge level of women sarpanch about fundamental functions of constitutional bodies and sponsored programme under Panchayati Raj System.

\section{Materials and Methods}

The study was conducted in Navsari district of South Gujarat during the year 2018-2019.Expost-facto research design was used for the study. Navsari district has six talukas. All six talukas were selected for present study. Total 168 Gram Panchayats of Navsari district are headed by women sarpanch. According to the number of Gram Panchayats headed by women sarpanch in each taluka, 100 villages were selected with proportionate random sampling. Thus, total 100 villages were selected from Navsari district. Respondents were selected with simple random sampling. Knowledge level was used as dependent variable to conduct the study. The interview schedule was prepared and respondents were interviewed at their home, office and farm. The collected data were analyzed by using percentage, mean, standard deviation, rank and correlation coefficient $(r)$.

\section{Results and Discussion}

Almost two decades into enactment of the $73^{\text {rd }}$ constitutional amendment act, for the obvious reason there is reportedly growing interest in the local government on women as representatives of Gram Panchayats.

The result of knowledge level about fundamental functions of constitutional bodies of all selected women sarpanch were presented in Table 1.

It was revealed from Table 1 that nearly two third of respondents (61.00 per cent) had medium level of knowledge followed by 27.00 per cent and 12.00 per cent had lower and higher level of knowledge about fundamental functions of constitutional bodies, respectively. The probable reason for the above finding might be medium level of education level.

The result of knowledge level about sponsored programme under Panchayati Raj System of all selected women sarpanch were presented in Table 2.

It was revealed from Table 2 that half of the respondents (50.00 per cent) have moderate level of knowledge followed by 34.00per cent and 16.00 per cent had lower and higher level of knowledge about sponsored programme under Panchayati Raj System, respectively. The probable reason for the above finding might be that there is no one who give the information about the new schemes to the panchayat members at village level. 
Table.1 Knowledge level of women sarpanch about fundamental functions of constitutional bodies

\begin{tabular}{|c|c|c|c|}
\hline \multirow[t]{2}{*}{ Sr. No. } & \multirow{2}{*}{$\begin{array}{l}\text { Categories of knowledge about } \\
\text { fundamental functions of } \\
\text { constitutional bodies }\end{array}$} & \multicolumn{2}{|c|}{ Respondents } \\
\hline & & Frequency & Percentage \\
\hline 1 & Lower (Up to 50.22 score) & 27 & 27.00 \\
\hline 2 & Moderate (50.23 to 61.52 score) & 61 & 61.00 \\
\hline 3 & Higher (61.53 and above score) & 12 & 12.00 \\
\hline & Total & 100 & 100.00 \\
\hline
\end{tabular}

Table.2 Knowledge level of women sarpanch about sponsored programme under Panchayati Raj System

\begin{tabular}{|c|c|c|c|}
\hline \multirow{2}{*}{ Sr. No. } & \multirow{2}{*}{$\begin{array}{l}\text { Categories of knowledge about } \\
\text { sponsored programme under } \\
\text { Panchayati Raj System }\end{array}$} & \multicolumn{2}{|c|}{ Respondents } \\
\hline & & Frequency & Percentage \\
\hline 1 & Lower (Up to 50.19 score) & 34 & 34.00 \\
\hline 2 & Moderate (50.20 to 61.81 score) & 50 & 50.00 \\
\hline 3 & Higher (61.82 and above score) & 16 & 16.00 \\
\hline & Total & 100 & 100.00 \\
\hline
\end{tabular}

It can be concluded that majority of respondents had moderate knowledge about fundamental functions of constitutional bodies and sponsored programme under Panchayati Raj System. It indicates that a rigorous exercise should be made by the governmental organization and collects the information regarding governmental policies and provided to Gram Panchayat. The almost success of the nationwide programme depends upon effective implementation at the village level by the Gram Panchayats. All that required is to motivate women to participate in socioeconomic and political activities needed for their development.

\section{References}

Batra, P. 2016. Participation and role performance of elected women representatives (EWRs) in gram Panchayat. Doctoral dissertation, (Unpublished) C.C.S.H.A.U.

Diwan, Y. B. 2007. A comparative study between the performance of man and women sarpanches Ahmadabad district of Gujarat. Ph.D. Thesis (Unpublished) A.A.U., Anand.

Kujur, A. 2008. A comparative study between the role performance of men and women Sarpanchs in Anand District of Gujarat State, M.Sc. Thesis, 
(Unpublished) A.A.U., Anand.

Nandal, V. 2013. Participation of women in panchayati raj institutions: a sociological study of Haryana, India. International Research Journal of Social Sciences.2(12):47-50.

Singh, S., Kumari, V. and Chander, S. 2013. Knowledge and involvement of elected women in various activities of gram panchayat. International Journal of Innovations in Engineering and Technology. Vol. 3 (1): 296-305.

Singh, S., Malik, J. S. and Singh, J. 2013. Role perception of gram panchayat members (GPMs). A Journal of Multidisciplinary Advance Research. Vol. 2:131-136.

\section{How to cite this article:}

Payal Patel and Naik, R. M. 2019. Knowledge Level of Women Sarpanch in Gram Panchayats of Navsari District of South Gujarat. Int.J.Curr.Microbiol.App.Sci. 8(12): 124-127. doi: https://doi.org/10.20546/ijcmas.2019.812.019 